\title{
Geomechanical Models and Prognosis of Stress-strain Behavior of Rock Ore in Development of Unique Deposits of Rich Iron Ores Under Water-bearing Formations
}

\author{
Vladimir Leonidovich Trushko and Anatoliy Grigoryevich Protosenya \\ The National Mineral Resources University (The Mining University), \\ Russia, 199106, Saint Petersburg, 21-st Line V.O., 2.
}

DOI: http://dx.doi.org/10.13005/bbra/1973

(Received: 25 September 2015; accepted: 19 November 2015)

\begin{abstract}
This paper gives a brief mining and geological description of the Yakovlevo deposit of rich iron ores of the Kursk magnetic anomaly (Russia), which is one of the largest by explored reserves of high quality ores (9.6 billion $\mathrm{mt}$ ) with iron content up to $69 \%$. For the assessment of physical and mechanical properties of ores and enclosing rocks, a testing procedure was developed, and a non-linear geomechanical model for the assessment of stress-strain state of rock ore and rocks masses around workings was proposed on the basis of the study. Tangential stress concentration coefficients on working's contour were calculated and zones of rock ore mass's limit state were identified. The calculation data agree with those found by experiment, giving ratios between working's breadth and roof arch height. Stress criterion for assessment of mine rocks around workings was developed, expressing the ratio of calculated stresses and calculated strength of rock mass, and recommendations were given on choosing kinds and parameters of supports for various stability categories of mine rocks outcroppings on workings' contours.
\end{abstract}

Key words: Iron ore, mines, mine rocks properties, geomechanical model, assessment of stability.

Basic resources of Russia's iron ore are concentrated within the Kursk magnetic anomaly ${ }^{1}$. 90.5\% of rich Kursk Magnetic Anomaly's (KMA's) ores by $\mathrm{A}+\mathrm{B}+\mathrm{C}_{1}$ categories and $96.9 \%$ by $\mathrm{A}+\mathrm{B}+\mathrm{C}_{1}+\mathrm{C}_{2}$ categories are concentrated in the Belgorod iron ore zone. It includes deposits of rich ores, unique in reserves and quality: Yakovlevo (9.6 billion $\mathrm{mt}$ ), Gostischevo (10.9 billion $\mathrm{mt}$ ), Bolshetroitskoye (1.5 billion $\mathrm{mt}$ ), Razumnoye, etc. Average iron content in ore exceeds $60 \%$. Deposits of rich iron ores of the Belgorod ore zone of the KMA are 500-1,000 m deep.

The Yakovlevo deposit is one of the largest deposits of high quality ores by discovered

* To whom all correspondence should be addressed. reserves with the highest iron content and the lowest harmful impurities (sulfur, phosphorus, etc.). Maximal depth of iron ores from the daylight surface exceeds 500 meters. Slope angles of ore bodies vary within $65-75^{\circ}$; in the northern part of the deposit they do not exceed $50^{\circ}$. Thickness of ore chute near lying side of banded iron formations is 20-30 $\mathrm{m}$, in middle part and hanging side it increases up to $100-200 \mathrm{~m}$. Besides hat-shape rich iron ore occurrence, the ores forming V-shaped and sheetlike bodies going rather deep are developed in the deposit.

The highest iron content is seen in ironmicaceous ores. In martite-hydrohematite and hydrohematite ores the iron content is lower. The iron content depends on the thickness of ore chute - increasing thickness, as a rule, causes iron 
content in ore to grow. In upper layers of deposits in the zone from several to $20-40 \mathrm{~m}$ thick, the iron content varies from 45 to $60 \%$. The zone from 10 20 to $200-250 \mathrm{~m}$ in the middle area of the Yakovlevo deposit contains up to $60 \%$ of iron. In the footwall, on the border with banded iron formation $0.5-12 \mathrm{~m}$ thick, the iron content decreases to $45-52 \%$.

Over $50 \%$ of the total reserves of the deposit are loose fine-pored iron-micaceous and martite iron-micaceous ores with typical bluish tint, while chloritic varieties are greenish. Hydrohematite martite ores are seen in selvages of ore body and form rather small thickness layers inside the ore chute. Martite hydrohematite ores are dark red, brown-red, brown-violet and make up $20 \%$ and $5 \%$ of iron ore reserves respectively. Hydrogoethite usually forms laminas of ochreish and brown-ochreish.

Textural features of rich iron ores determine the strength and deformation parameters of ores which should be accounted for in the assessment of outcroppings, especially in the conditions of high water absorption. In soft, unsound ores, iron mica flakes $0.2-0.5 \mathrm{~mm}$ long are seen, the content of which reaches $75-80 \%$. Hematite in the modification of iron ore mica is characterized by parallel and subparallel location ${ }^{2}$.

In the cross-section of the deposit, seven aquifers divided into two hydraulically isolated complexes are seen. The lower layer is represented by Callovian, black coal (carbon) and ore crystalline aquifers. The latter relates to the upper fractured zone of the crystalline core-area, faulted zones and rock ore. Five aquifers, as on the beginning of mining works, had great water abundance and water height up to $405-610 \mathrm{~m}^{3-4}$.

Argillaceous deposits in footwalls of carbonic rocks, solid residual ores and carbonized bauxite formations in the roof of the ore crystalline layer with total thickness from 2 to $60 \mathrm{~m}$ prevent the interaction between carbonic and ore crystalline aquifers. Drainage of the ore crystalline core-area slightly decreased the level of groundwater in the carbonic layer. Low hydraulic link between the layers was noted. Meantime, it is prognosticated that flooding of mine workings will be caused by the hydraulic link between the carbonic and the ore crystalline aquifers. In that connection, prevention of deformations of the dividing layer during extraction is of great importance.

The basic parameters of physical and mechanical properties of the Yakovlevo deposit ores are listed ${ }^{5}$ in Table 1 . The properties of various mineralogical structure ores are greatly differing. The most porous, hydrophilic and soft are loose claylike varieties of goethite ores, capable to bind a lot of water and maximally decrease its strength upon extra moisturizing respectively.

\section{Methodology}

The studies of ore samples in laboratory conditions were done using pressure equipment for the analysis of physical and mechanical properties of rocks and materials during axial compression at various levels of uniform compression pressure varying from 0 to $300 \mathrm{MPa}$ ensuring stress condition $\sigma_{1} \geq \sigma_{2}=\sigma_{3}$. The equipment allows to study compression, filtering and deformation properties of rocks and materials during deformation process at an ambient temperature.

Uniaxial compression tests were done on cylinder shape samples $(\mathrm{d}=30 \div 56 \mathrm{~mm})$, diameter/ height ratio 1/2. Non-parallelism of butt ends of each sample did not exceed $0.02 \mathrm{~mm}$. In finding the deformation parameters for each level of stress condition the samples rocks variety was represented by $6 \div 8$ samples.

Hydroinsulation of samples was done using polyethylene tube made of polyethylene film $0.3 \div 0.5 \mathrm{~mm}$ thick or a special rubber boot. Tube ends with inserted sample are placed on special heel sockets which tightly press them with steel bushings.

The study of mechanical properties of ore and rocks at press velocity of deformation $\varepsilon_{1=} 10^{-}$ ${ }^{4} \mathrm{~S}^{-1}$ and temperature $t=20-22^{\circ} \mathrm{C}$ was done during longitudinal uniaxial compression of cylinder samples and during compression in triaxial stress.

The range of uniform compression pressure was $\sigma_{2}=\sigma \mathrm{s}_{3}=0-25 \mathrm{MPa}$ which corresponds to the kind of stress condition in which strength passports of studied ores flatten.

Tests in complex stress condition were done using cylinder shape samples. Sample sizes: diameter $55 \pm 1 \mathrm{~mm}$, height $100 \pm 1 \mathrm{~mm}$. A sample with installed lateral deformation sensor was placed between plates. To release stress concentration and ensure its equal distribution on ends, annealed foil $0.1 \mathrm{~mm}$ thick was placed between sample's end 
and upper pressing surface of heel socket.

Slope of fall characterizes the rock brittleness and slope modulus $\subset$ is a quantity parameter of brittleness ${ }^{6}$.

The diagrams stress/deformation, besides elastic constants and over-limit conditions allow to obtain the states of limit conditions: elastic limit states, tensile strength states, residual strength states. It is generally accepted to use Mohr's circles to represent limit conditions of rocks. Ore - rock and half-rock, hydrohematite-martite, chloritic, banded and martite-goethite-hematite, chloritic, carbonized, breccia. Triaxial compression range was: $\sigma_{2}=\sigma_{3}=0 ; 2.0 ; 5.0 ; 10 ; 15 \mathrm{MPa}$.

\section{RESULTS}

Visual inspection of samples allows to conclude that the rock samples submitted have massive banded structure with angle of fissility slope up to $45^{\circ}$ to the vertical axis. More detailed analysis of the velocity of ultrasonic waves advance showed that the velocity of lateral waves advance in two mutually perpendicular directions is controversial.

In the fissility plane the velocity of lateral waves is approximately twice as low as that of longitudinal waves (generally accepted). When source is turned by $90^{\circ}$ the velocity of lateral wave decreases by $15-20 \%$. That evidences the existing fracturing in perpendicular fissility plane. The ultrasonic waves advance velocity for the same rock does not depend on depth which evidences developed fracturing in perpendicular fissility plane. From the analysis of velocity advance of ultrasonic waves it follows that the most destroyed rocks are rock ore and half-rock ore, hydrohematitemartite.

For results analysis, differential normal stress was used, calculated using equation (1):

$$
\Delta \sigma_{1}=\sigma_{1}-\sigma_{2}
$$

compression pressure.

Table 2 lists principal stresses $\Delta \sigma_{1}{ }^{\max }$, $\Delta \sigma_{1}{ }^{\text {res }}$ at maximal and residual strength sections, Poisson ratio, elasticity modulus $E$, slope $M$ and stress $\sigma_{2}$

The ores studied show weak dependency on the change of stress condition. With the growth of triaxial compression, the strength of some samples did not virtually change compared to uniaxial compression strength. For such samples, stress/deformation diagram was flattening.

Generalized experimental dependencies between the largest shear $\gamma=\varepsilon_{1}-\varepsilon_{2}$ and the highest shear stresses $\mathrm{t}_{\max }=0.5\left(\sigma_{1}-\sigma_{3}\right)$, where $\varepsilon_{1}, \varepsilon_{2}-$ principal relative deformations, for carbonized solid iron-micaceous rock martite and carbonized solid hydrohematite ores are shown on Figures 1 and 2 respectively.

The dependencies of ores deformation (Figures 1,2), received during the hard press tests show that the dependencies between stress and deformations are non-linear.

To study the stress-strain behavior of the rock mass around mine workings beyond elastic limit, physically nonlinear body model was used in the form of equations [7-8] of deformation plasticity theory (2):

$$
\begin{aligned}
& \varepsilon_{1}-\varepsilon_{2}=\psi\left(\sigma_{1}-\sigma_{2}\right) ; \quad \varepsilon_{2}-\varepsilon_{3}=\psi\left(\sigma_{2}-\sigma_{3}\right) ; \\
& \varepsilon_{3}-\varepsilon_{1}=\psi\left(\sigma_{3}-\sigma_{1}\right),
\end{aligned}
$$

where y - scalar function based on experimental data; $\varepsilon_{1}, \varepsilon_{2}, \varepsilon_{3}$ - principal deformations; $\sigma_{1}, \sigma_{2}, \sigma_{3}$ - principal stresses.

The analysis of experimental data (Figures 1,2) on rocks deformation in triaxial stress state shows that the dependency between the largest shear $g$ and the maximal shear stress $t$ for deformation plasticity theory may be written as (3):

$$
\gamma=2 \mathrm{~B} \tau^{\mathrm{m}+1}
$$

where $B, m$ - constant values obtained upon approximation of experimental data (Figures $1,2)$.

For round shape cross-section working made at the depth $\subseteq$ from the surface with initial hydrostatic stress condition, the components of radial $\mathrm{s}_{r}$ and shear (tangential) $\mathrm{s}_{q}$ stresses are as follows (4):

$$
\sigma_{\mathrm{r}}=\gamma \mathrm{H}-(\gamma \mathrm{H}-\mathrm{p}) \mathrm{r}-\frac{2}{1+\mathrm{m}} ; \sigma_{\theta}=\gamma \mathrm{H}+(\gamma \mathrm{H}-\mathrm{p})\left(\frac{1-\mathrm{m}}{1+\mathrm{m}}\right) \mathrm{r}^{-\frac{2}{1+\mathrm{m}}} \ldots
$$

where $r$ - non-dimensional radial coordinate; $p$ - support's reaction, $\gamma-$ specific weight of rocks.

Stress concentration factor $K$ on working's contour depends on nonlinearity parameter $m$ and support's reaction (5): 


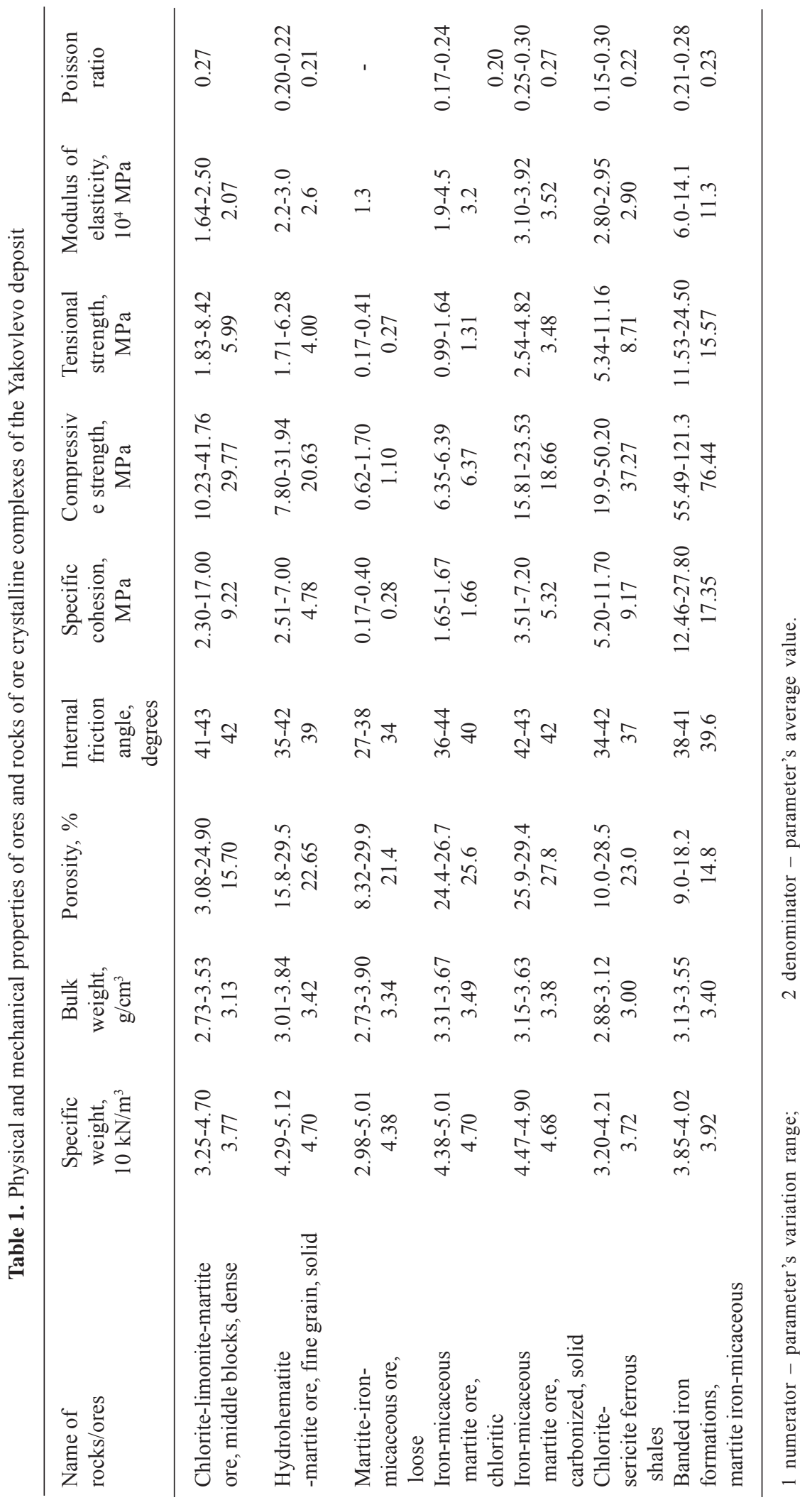




$$
K=\frac{\sigma_{\theta}}{\gamma H}=\frac{2}{1+m}-\frac{1-m}{1+m} \frac{p}{\gamma H} .
$$

To find shear stress concentration factors on the contour of a single domed shape preparatory working accounting for physically nonlinear model of rock mass deformation, two-dimensional finite element model was built [9]. Computation model is shown on Figure 3.

Natural stress-strain behavior of the rock mass was found on the assumption that workings are located $500 \mathrm{~m}$ deep in non-uniform compression field distributed through the whole volume of surrounding rock mass with the components $\sigma_{\mathrm{Y}}=$ $\gamma \mathrm{H}, \sigma_{\mathrm{X}}=0.5 \gamma \mathrm{H}$, where $\sigma_{\mathrm{Y}} \sigma_{\mathrm{X}}-$ vertical and horizontal stress in unmined rock mass.

Upon the modeling, shear stress concentration factors in dome shape working's contour were obtained (Table 3 ). The nature of shear stress concentration factor's distribution on dome shape working's contour is shown on Figure 4.

The analysis showed that for the working made in iron-micaceous-martite and hydrohematitemartite ores of average strength, maximal stress on the contour as per nonlinear theory were $\sigma_{\theta}=$ $1.84 \gamma \mathrm{H}$ and $\sigma_{\theta}=1.72 \gamma \mathrm{H}$ respectively. The highest values of stress concentration factors in the first case were observed on springing block level, in the second case - on working's soil. On the level of springing block in the first case, theory of elasticity increases stress concentration factor 1.64 times, in the second case -1.9 times.

On the level of soil, for a working made in iron-micaceous-martite ore of average strength,

Table 2. Results of study of strength and deformation parameters of ores (iron-micaceous-martite, chloritic with hydrohematite, massive indistinctly banded structure, brecciated fractured ore)

\begin{tabular}{|c|c|c|c|c|c|}
\hline$\Delta \sigma_{1}^{\max }, \mathrm{MPa}$ & $\Delta \sigma_{1}^{\text {res }}, \mathrm{MPa}$ & $\mathrm{E} \cdot 10^{4}, \mathrm{MPa}$ & $v$ & $\mathrm{E} \cdot 10^{4}, \mathrm{MPa}$ & $\sigma_{2}, \mathrm{MPa}$ \\
\hline 10.8 & 7.0 & 0.56 & 0.06 & 0.15 & 0 \\
\hline 14.2 & 7.2 & 0.76 & 0.10 & 0.51 & 0 \\
\hline 21.8 & 14 & 0.4 & 0.08 & 0.26 & 0 \\
\hline 44.5 & 14.13 & 1.08 & 0.19 & 1.04 & 0 \\
\hline 34.5 & 12.4 & 1.15 & 0.15 & 0.29 & 0 \\
\hline 6.4 & 4.7 & 0.25 & 0.11 & 0.11 & 1 \\
\hline 12.5 & 7.9 & 0.17 & 0.08 & 0.076 & 2 \\
\hline 39.9 & 28.5 & 0.41 & 0.08 & 0.2 & 5 \\
\hline 12.5 & 12.5 & 0.057 & - & - & 5 \\
\hline 23.2 & 15.2 & 0.21 & 0.07 & 0.032 & 2 \\
\hline 64.3 & 40.9 & 2.14 & - & 0.53 & 2 \\
\hline 26.8 & 14.7 & 0.87 & - & 0.62 & 2 \\
\hline 45.6 & 33.3 & 1.52 & 0.13 & 0.22 & 2 \\
\hline 39.9 & 28.5 & 0.41 & 0.08 & 0.2 & 5 \\
\hline 12.5 & 12.5 & 0.057 & - & - & 5 \\
\hline 46 & 38.4 & 0.63 & - & 0.3 & 5 \\
\hline 93.8 & 40 & 2.3 & 0.18 & 2.25 & 5 \\
\hline 14.82 & 11.02 & 0.13 & - & 0.0068 & 10 \\
\hline 33.26 & 22.68 & 0.655 & - & 0.0246 & 10 \\
\hline 48.6 & 45.9 & 0.26 & 0.06 & 0.06 & 10 \\
\hline 55.6 & 53.6 & 1.21 & 0.22 & 0.06 & 10 \\
\hline 89.1 & 68.3 & 3.0 & 0.29 & 0.43 & 10 \\
\hline 72.6 & 49.89 & 2.9 & 0.18 & 0.63 & 15 \\
\hline 43.1 & 42 & 0.54 & 0.21 & 0.30 & 15 \\
\hline 54 & 45.2 & 0.65 & 0.17 & 0.14 & 15 \\
\hline 89.8 & 73.7 & 1.83 & 0.21 & 0.28 & 15 \\
\hline 118.6 & 97.8 & 2.98 & 0.22 & 0.52 & 15 \\
\hline 88.4 & 71.7 & 2.6 & 0.13 & 0.35 & 15 \\
\hline
\end{tabular}


Table 3. Results of calculations of stress concentration factors $\mathrm{s}_{\mathrm{q}}$ on dome shape working contour for various types of the Yakovlevo deposit ores

\begin{tabular}{lccc}
\hline Contour area & \multicolumn{1}{c}{$\begin{array}{c}\text { Stress concentration factor s on the } \\
\text { contour in } \gamma \mathrm{H} \text { portions according to theory }\end{array}$} & $\begin{array}{r}\text { Stress growth factor as per } \\
\text { linear theory compared }\end{array}$ \\
\cline { 2 - 3 } & linear & non-linear & to non-linear \\
\hline $\begin{array}{l}\text { Iron-micaceous-martite ore } \\
\text { chloritic, average strength }\end{array}$ & & & 0.91 \\
Roof & 0.78 & 0.86 & 1.64 \\
Springing block & 3.01 & 1.84 & 1.71 \\
Side & 1.54 & 0.90 & 1.53 \\
Soil & 2.52 & 1.65 & 1.0 \\
carbonized, solid & & & 1.28 \\
Roof & 0.78 & 0.78 & 1.12 \\
Springing block & 3.01 & 2.35 & 1.51 \\
Side & 1.54 & 1.37 & \\
Soil & 2.52 & 1.67 & 0.98 \\
Hydrohematite-martite ore & & & 1.90 \\
chloritic, average strength & & & 1.90 \\
Roof & 0.78 & 0.80 & 1.47 \\
Springing block & 3.01 & 1.58 & 1.11 \\
Side & 1.54 & 0.81 & 1.55 \\
Soil & 2.52 & 1.72 & 1.43 \\
carbonized, solid & & 0.70 & 1.93 \\
Roof & 0.78 & 1.08 & \\
Springing block & 3.01 & & \\
Side & 1.54 & & \\
Soil & 2.52 & & \\
\hline & & & \\
\hline
\end{tabular}

Table 4. Filed data of roof arch height

\begin{tabular}{lccc}
\hline $\begin{array}{l}\text { Sequence number of arch } \\
\text { from crosscut No. } 2\end{array}$ & $\begin{array}{c}\text { Breadth of working's arch } \\
\text { drifting } B_{\mathrm{w}}, \mathrm{m}\end{array}$ & $\begin{array}{c}\text { Arch height } h_{\mathrm{a}}, \\
\mathrm{m}\end{array}$ & Ratio $h_{\mathrm{a}} / B_{\mathrm{w}}$ \\
\hline 2 & 6.50 & 2.70 & 0.42 \\
4 & 6.54 & 2.88 & 0.43 \\
6 & 6.78 & 2.43 & 0.42 \\
8 & 6.04 & 2.46 & 0.41 \\
10 & 6.21 & 2.95 & 0.47 \\
22 & 6.29 & 2.69 & 0.43 \\
24 & 6.38 & 2.80 & 0.44 \\
26 & 6.88 & 2.88 & 0.42 \\
28 & 6.38 & 2.41 & 0.38 \\
Average value & 0.42 & & \\
\hline
\end{tabular}

Table 5. Stability categories of mine working outcroppings

\begin{tabular}{ll}
\hline $\mathrm{P}_{\mathrm{B}}$, category and stability state of rocks & Rock mass deformation models \\
\hline I category - stable condition, $\mathrm{P}_{\mathrm{B}}<1.0$ & Pre-limit linear and nonlinear deformation \\
II category - limit condition, $\mathrm{P}_{\mathrm{B}}=1.0-1.3$ & Near-contour area of rock mass turns into limit state \\
III category - unstable condition, $\mathrm{P}_{\mathrm{B}}=1.3-3.0$ & Limit state zone is formed around working \\
IV category - rather unstable condition, $\mathrm{P}_{\mathrm{B}}>3.0$ & Limit state zone and roof arch are formed around working
\end{tabular}




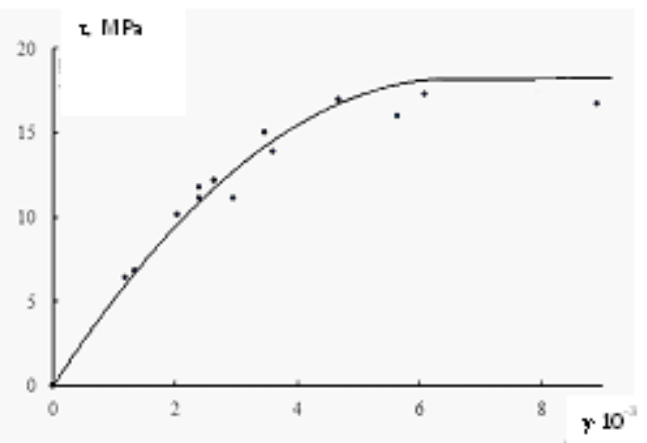

Fig. 1. Generalized experimental dependencies between the largest shear and the highest shear stresses for carbonized solid iron-micaceous rock martite ore

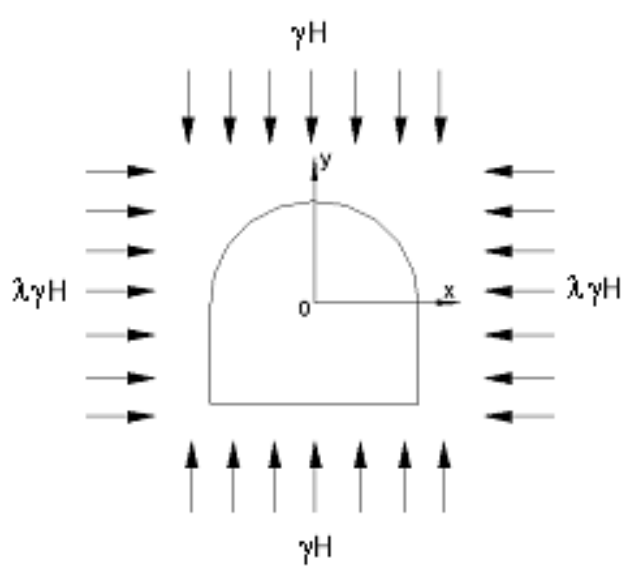

Fig. 3. Computation model

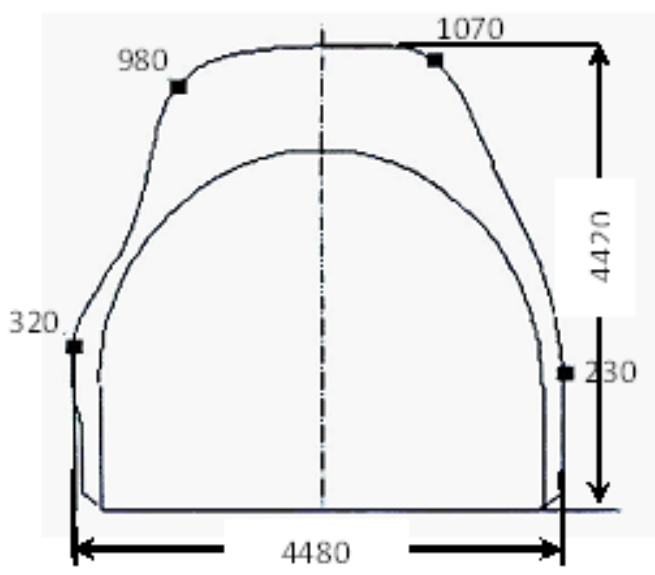

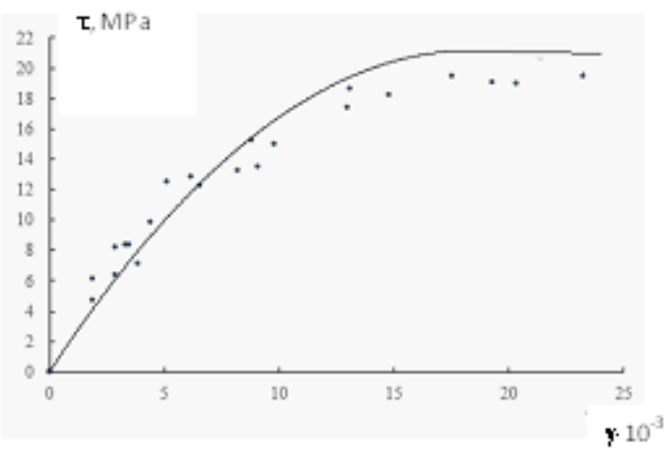

Fig. 2. Generalized experimental dependencies between the largest shear and the highest shear stresses for carbonized solid hydrohematite ore

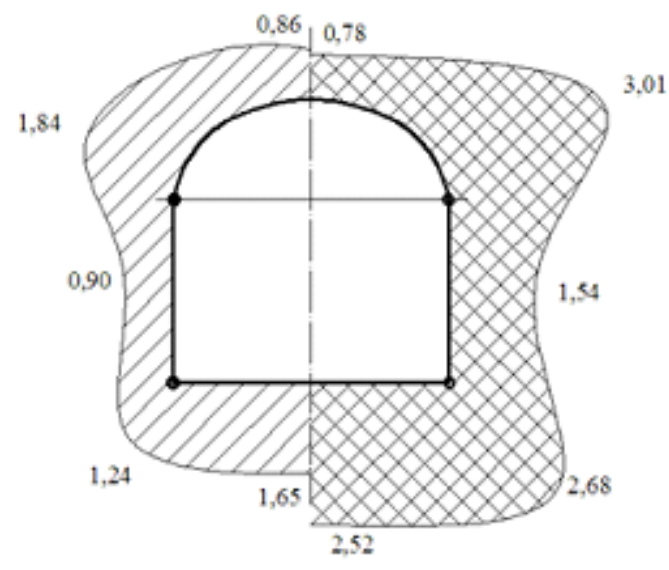

Fig. 4. Distribution of shear stress concentration factor $\mathrm{K}_{\dot{\mathrm{e}}}$ on dome shape working contour for ironmicaceous ore of average strength (left: according to nonlinear theory; right: according to linear theory)

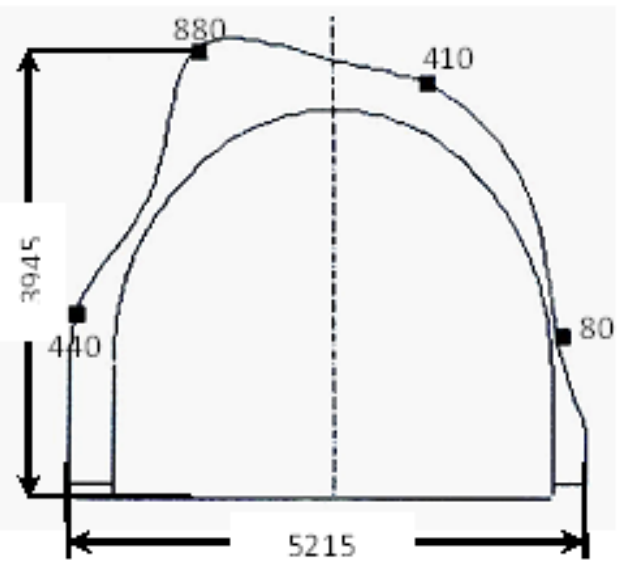

Fig. 5. Contours of mine workings surface outcroppings 
overstress factor was 1.53, in hydrohematite ore of average strength -1.47 . Like in the case with round shape working, the effect of medium's nonlinearity decreases as the ore strength grows.

For a working made in solid ironmicaceous-martite carbonized ore, maximal contour stress, according to nonlinear theory, were $\sigma_{\theta}=$ $2.35 \gamma \mathrm{H}$, in hydrohematite-martite solid carbonized ore $-\sigma_{\theta}=1.93 \gamma \mathrm{H}$. In this case, the highest values of concentration factors were observed at the level of working's springing block. On the soil level, in the first case, theory of elasticity increases stress concentration factor 1.51 times, in the second case -1.71 times.

Thus, accounting for the nonlinearity of rock ore mass deformation in low ad average strength ores causes the decrease of maximal shear stress concentration factors on dome shape working's contour 1.5-2 times, in more solid carbonized ores $-1.3-1.7$ times.

To find the nature of loose ores deformation around workings, special experiments were done. The results of field observations of roof outcropping in loose ores show that outcropping contour has the vertical dome shape (Figure 5). Therefore, for calculation of support load in loose ore workings, dome theory may be applied.

Limit state of loose ores at triaxial stress is described by Coulomb's equation (6):

$$
\tau=C+\sigma_{\mathrm{p}} \operatorname{tg} \rho,
$$

where $C$ - cohesion of loose ore; $\mathrm{t}$ - the highest shear stress on shear area; $\sigma_{p}$ - normal stress on shear plane; $r$ - internal friction angle.

Roof arch height above working in loose ores with natural moisture is found using P.I. Tsimbarevich's formula (7) [10]:

$$
h_{a}=\frac{B}{2 \operatorname{tg} \beta}
$$

where $B$-working's breadth; $\mathrm{b}$ - seeming internal friction angle linked with internal friction angle via dependency (8):

$$
\frac{C}{\sigma_{p}}+\operatorname{tg} \rho=\operatorname{tg} \beta
$$

To find angle $\mathrm{b}$ using formula (8), we use the experimental data on loose ore destruction.
During uniaxial compression, ores destruction occurs at $45^{\circ}$. Then, limit normal stress on shear area $\sigma_{\mathrm{p}}=\sigma_{\lim } \cos 45^{\circ}=1.1 \frac{\sqrt{2}}{2}=0.77 \mathrm{MPa}$. At given stress and $C=0.28 \mathrm{MPa}, \mathrm{r}=34^{\circ}$ the value $\operatorname{tg}$ of seeming internal friction angle $\operatorname{tg} \beta=1.03$.

At $\operatorname{tg} \beta=1.03$ the ratio between working's width and roof arch height found using formula (7), will equal $\mathrm{h}_{a}=0.48 \mathrm{~B}$.

\section{DISCUSSION}

To check the above ratio, filed observations were made over the size of limit state arch obtained in the experimental working in loose ore at $-425 \mathrm{~m}$ (the Yakovlevo deposit).

Table 4 submits the field-measured working's arch breadth $B$, its height $h_{a}$ and their ratio. The measurements were done by probing working's area behind support (KMP-A3: metal compressible support, arched, three-chain) by finished cross-section $18.8 \mathrm{~m}^{2}$, excavation span $5.1 \mathrm{~m}$ and arch working height $1.84 \mathrm{~m}$. From Table 4 it follows that $h_{\mathrm{a}}=0.42 B$. It should be noted that similar results of field measurements were obtained for other workings. Results comparison shows that estimated and field data match on finding the size of limit condition arch above the mine working. For computations, we take the average height of $\operatorname{arch} h_{\mathrm{a}}=0.45 B$.

Moisture causes the decrease of ore's strength parameters and may cause swallet ${ }^{11-17}$.

To assess cohesion and internal friction angle for iron-micaceous-martite and martite ores in the course of time, prof. R.E. Dashko did the tests at humidity of 10-16.5\%. Tests under 0.5 month were done on samples taken in workings. Test results showed that moisturizing samples reduces the cohesion in rich iron ores by $40 \%$ and internal friction angle by $45 \%$. Tests after $1.5-2$ and more months were done after samples storing and water saturation. Tests done in 2005 on rich ore samples taken from transportation crosscut at humidity $11.4-13.6 \%$ showed cohesion $C=0.52$ $0.57 \mathrm{MPa}$ and internal friction angle $\rho=8-9^{\circ}$.

The calculation using the above methodology of seeming internal; friction angle for water-bearing loose ores $\operatorname{tg} b$ at $C=0.28 \mathrm{MPa}$ and $\rho=6^{\circ}$ shows that for the above values of $C$ 
and $\rho$ the value of $\operatorname{tg} \beta=0.72$. At this angle $\beta$ the ratio between working's breadth and roof arch height found using formula (7), will be $h_{\mathrm{a}}=0.69 \mathrm{~B}$. The calculation under the above methodology for loose ores with strength parameters $C=0.52 \mathrm{MPa}$, $\mathrm{r}=8^{\circ}$ and $C=0.38 \mathrm{MPa}, \mathrm{r}=13^{\circ}$ shows that the ratio between breadth and roof arch height was, respectively, $h_{\mathrm{a}}=0.65 B$ è $h_{\mathrm{a}}=0.63 B$.

The average value for the three completed calculations $h=0.65 B$.

Based on the above, roof arch height $h_{\mathrm{a}}$ (Figure 5) over mine working (dome and trapezoid shape, cross-section in loose ores) is found using the formula $h_{a}=n B$, where $B$ - working breadth on roof level, $\mathrm{m} ; n$ - ore strength and rock fall height parameter, $\mathrm{n}=0.45$ - for natural moisture ores, $\mathrm{b}=0.65$ - for water-saturated rock ore mass.

Vertical evenly distributed load on mine working's supports is found according to arch theory $\mathrm{P}_{\mathrm{B}}=2 \gamma \mathrm{h} / 3$ where $\mathrm{g}$ - volume weight, $\mathrm{kN} / \mathrm{m}^{3}$. Horizontal evenly distributed load on support $\mathrm{P}_{2}=\gamma(\mathrm{h}+0.5 \mathrm{~h}) \operatorname{tg}^{2}(45-\beta / 2)$.

\section{CONCLUSION}

Working's stability is assessed via stress criterion for its elements (roof and sides) expressing the ratio of calculated stress (numerator) and calculated strength (denominator) (9) ${ }^{18-19}$ :

$$
P_{B}=\frac{\sigma K_{1} K_{2}}{R K_{s} \xi_{B}}
$$

where $\sigma$-static vertical stress in unmined rock ore mass in the place of working's location, $\mathrm{MPa} ; K_{1}$ stress concentration coefficient due to working; $K_{2}$ - stress change coefficient upon the impact of other workings; $R$-average resistance of rocks in sample to uniaxial compression at short-time loading, MPa; $K_{\mathrm{s}}$ - coefficient of structured relaxation of the rock mass due to fracturing, fissility and microinhomogeneities; $\xi_{\mathrm{B}}$ - factor accounting for rocks resistance due to water saturation equal to limit strength in water-saturated and natural states.

Stress concentration coefficient $K_{1}$ for cross-section dome shaped workings are listed in Table 3. The value of $K_{2}$ is found, like $K_{1}$, from the solution of the task on workings interaction using finite elements method or its values specified in [5] may be used.
Average value of resistance $R$ of ores and rocks is found from Table 1.

Structured relaxation $K_{\mathrm{s}}$ is suggested to be found according to SNiP II-94-80 (Construction norms and rules) upon quantity analysis of rocks disturbance in designed place of working based on engineering and geological studies of average distance between rocks relaxation surfaces [20].

$P_{E}$ using formula (9) should be found separately for roof and sides.

By $\mathrm{P}_{\mathrm{B}}$ criterion, stability of mine workings outcroppings is divided into four categories of stability (Table 5).

For the first category of stability, full-time support is not required. Regular inspections of workings are required and contour scaling in roof break points.

For stability category II, roof bolting with metal wire netting on the roof and sides. Swellex type bolting $1.8 \mathrm{~m}$. Net $0.7^{\prime} 0.7$ to $1.0^{\prime} 1.0 \mathrm{~m}$. The distance from the low row of bolting to working's ground up to $1.2 \mathrm{~m}$.

For stability category III, metal compressible arch-shape support KMP-A3 is recommended made of special replaceable profile SVP-22 and SVP-27 with metal meshy bolting of roof and sides. Backing space behind support. Arch span 0.75-1.0 m.

For stability category IV, metal arch support with welded metal meshy bolting and backing space behind support is recommended. Safe supports. arch span 0.5-0.75 m. SVP-22 and SVP-27 support elements with foothold for piles. Middle bolting (piles, capping).

The research allows to reasonably apply the geomechanical model of physically nonlinear body to calculate stress-strain behavior of rock mass around workings and make recommendations on stability.

Of further interest is finding the highest concentration of tangential stress on mine working's contour using nonlinear dependencies. It will enable to assess the field of applicability of physically nonlinear body, find real values of stress concentration coefficients using nonlinear diagram of stress and strain and finally, due to decrease of those coefficients, cut the costs on ensuring mine workings stability. 


\section{REFERENCES}

1. Sokolov, G.A. and N.A. Bykhover, 1969. Geology, Hydrogeology and Iron Ores of the Kursk Magnetic Anomaly. Moscow: Nedra.

2. Trushko, V.L., A.G. Protosenya and R.E. Dashko, Geomechanical and Hydrogeological Issues of the Yakovlevo Deposit Development. Proceedings of the Mining Institute, 2010; 185: 9-18.

3. Dashko, R.E., Engineering and Geological Characteristic and Assessment if Rich Iron Ores of the Yakovlevo Mine. Proceedings of the Mining Institute, 2006; 168: 97-104.

4. Dashko, R.E. and Ye.N. Kovalyova, Comprehensive Monitoring of Ground Waters in the Yakovlevo Deposit of Rich Iron Ores and Its Role in Mining Safety Improvement in Undrained Aquifers Condition. Proceedings of the Mining Institute, 2011; 190: 78-85.

5. Protosenya, A.G. and V.L. Trushko, Prognostication of Workings Stability in Loose Iron Ores of the Yakovlevo Deposit. Physical and Technical Issues of Mineral Wealth Development, 2013; 4: 1-13.

6. Stavrogin, A.N. and A.G. Protosenya, Mechanics of Mine Rocks Deformation and Destruction. Moscow: Nedra, 1992.

7. Stavrogin, A.N. and A.G. Protosenya, Strength of Mine Rocks and Workings Stability at Deep Depth. Moscow: Nedra, 1985.

8. Protosenya, A.G. and M.O. Lebedev, Calculation of Load on Subway Tunnel Casing in Soil Masses. Physical and Technical Issues of Mineral Wealth Development, 2002; 4: 14-18.

9. Morozov, Ye.M. and G.P. Nikishkov, Finite Elements Method in Fracture Mechanics. Moscow: Nauka, 1980.

10. Tsimbarevich, P.M., Mine Rocks Mechanics (2nd ed., fully revised). Moscow: Ugletekhizdat. Dashko, R.E. and A.V. Volkova, 2006. Study of Ground Water Invasion from Low Carbonic Aquifer into Mine Workings of the Yakovlevo Mine. Proceedings of the Mining Institute, 1948;
168: 142-149.

11. Dashko R.E., Volkova A.V., Study the possibility of breakthroughs groundwater from Lower Carboniferous aquifer in mine workings Yakovlevsky mine. Zapiski gornogo institute, V. 2006; 168: 142-149.

12. Peng, S., Investigation of Engineering Disasters Induced by Coal Mining at Deep Depth in China. In 4th Ann meeting, Geology Branch, China Coal Industry Tech Committee, Qingdao. (In Chinese), 1997.

13. Peng, S., The State-of-Art and the Future Work of Engineering Disasters Induced by Coal Mining at Deep Depth in China. In Symposium on Engineering and Disaster, Dept Material Science and Engineering, China NSF, Mt Jiuhua, Jianxi,. 1999. (In Chinese).

14. Zhang, J. and B. Shen, Coal Mining under Aquifers in China: A Case Study. Int. J. Rock Mech. Min. Sci., 2004; 4(41): 629-639.

15. Zhang, J., Theory and Practice on Prediction of Water Inrushes from Coal Seam Floor. Coal Geology and Exploration, 1989; 4: 38-41. (In Chinese).

16. Zhang, J., Theoretical Criterion of Water Inrushes from Confined Aquifers under Coal Seams and its Application. Mechanics and Practice, 1990; 12: 35-38. (In Chinese).

17. Zhang. J., Investigations of Water Inrushes from Aquifers under Coal Seams. Int. J. Rock Mech. Min. Sci., 2005; 3(42): 350-360.

18. Trushko, V.L., A.G. Protosenya and V.F. Plaschinskiy, Assessment of Stability of Outcroppings and Calculations of Load on support in the Yakovlevo Mine Workings. Proceedings of the Mining Institute, 2006; 168: 115-122.

19. Trushko, V.L., A.G. Protosenya, P.F. Matveyev and Kh.M. Sovmen, Geomechanics of Masses and Dynamics of Deep Mine Workings. Saint Petersburg: Saint Petersburg Mining Institute, 2000.

20. SNiP II-94-80, Underground Mine Workings. Moscow, 1980. 